УДК $37: 355$

DOI:

Олег Колісник, кандидат психологічних наук, підполковник, заступник начальника науково-дослідного відділу військово-гуманітарних досліджень

Військового інституту Київського національного університету імені Тараса Шевченка

\title{
СУЧАСНІ ПІДХОДИ ДО ФОРМУВАННЯ НАЦІОНАЛЬНОЇ СВІДОМОСТІ ТА ПАТРІОТИЗМУ У КУРСАНТІВ ЗАКЛАДІВ ВІЙСЬКОВОЇ ОСВІТИ
}

Стаття присвячена пошуку ефективних методів патріотичного виховання курсантів закладів військової освіти. Зазначена низка проблем, щуо перешкоджають формуванню національної свідомості та патріотизму курсантів. Запропоновано комплексний підхід до проведення педагогічно-патріотичних заходів. впровадження сучасних методів патріотичного виховання; вдосконалення просвітницько-виховних методологій з застосуванням інноваційних освітніх технологій; поглиблення вивчення історії багатовікового національно-визвольного руху украӥнського народу; зміинення морально-духовних якостей курсантів та прищеплення їм переконання в необхідності дотримання здорового, спортивного образу життя.

Ключові слова: військова педагогічна методологія; формування начіональноӥ свідомості; національнопатріотичне виховання; курсанти закладів військової освіти; майбутні офіцери; військово-патріотичні заходи.

Jim. 5.

Oleh Kolisnyk, Ph.D.(Psychology), Lieutenant Colonel

Deputy Chief of the Research Department of Military and Humanitarian Studies of the Military Institute of the Kyiv Taras Shevchenko National University

\section{MODERN APPROACHES TO FORMATION OF NATIONAL CONSCIOUSNESS AND PATRIOTICISM IN CADETS OF MILITARY EDUCATION INSTITUTIONS}

The article highlights the acute need of improving national-patriotic education of cadets of military education institutions, taking into account the specificity and differences between military and general pedagogy, is emphasized on the need to adjust the educational process, in view of the peculiarities of the historical and political circumstances of the country. It is stressed on the importance of searching modern effective methods of patriotic education of future officers in military education establishments for the in-depth disclosure of patriotism as a high moral and spiritual value. The author presents grounds for individual approach to the development of each individual person in the pedagogical process, taking into account the personal qualities of each cadet. The article underlines the fundamental component of national patriotic education in the formation of a professional military man. It is accentuated on the necessity of state support for the program of national-patriotic education and state guarantee of a decent level of social security for servicemen. The author addresses the problems of long-term neglect of the state in ensuring a decent level of social security of the officer's profession and the crisis in understanding of the patriotic qualities of a serviceman, low level of national dignity. The main features of modern high-level officer are determined. The complex approach to preparation and conducting pedagogical-patriotic measures is proposed: introduction of the latest methods of patriotic education; improvement of educational methodologies by the use of innovative educational technologies; deepening the study of the history of the centuries-old national liberation movement of the Ukrainian people; strengthening the moral and spiritual qualities of cadets and inculcating them the belief in the need to adhere to a healthy, sporty way of life.

Keywords: military pedagogical methodology; formation of national consciousness; national patriotic education; cadets of military education institutions; future officers; military patriotic measures.

П остановка проблеми. Продовження російської військової агресії на сході України все більше актуалізує проблемупідвищення рівня професійної підготовки майбутніх офіцерів. Стрижнем такої підготовки та запорукою потужної національної армії України $\epsilon$ професійно i патріотично налаштовані військовослужбовці. Для ефективної мотивації майбутніх офіцерів мати бажання щиро захищати свою країну, а не просто отримати забезпечену пільгами військову професію, дуже важливо приділити ретельну увагу національнопатріотичному вихованню курсантської молоді, яка $€$ фундаментальною складовою їх військової підготовки. Пошук ефективних методів патріотичного виховання майбутніх учасників бойових дій та формування національної свідомості, готовності до жертовності заради незалежності та територіальної цілісності батьківщини є першочерговим завданням навчально-виховного процесу курсантів у закладах військової освіти. 


\section{СУЧАСНІ ПІДХОДИ ДО ФОРМУВАННЯНАЦІОНАЛЬНОӤ СВІДОМОСТІ ТАПАТРІОТИЗМУ У КУРСАНТІВ ЗАКЛАДІВ ВІЙСЬКОВОЇ ОСВІТИ}

Аналіз останніх досліджень і публікацій. У наукових працях вітчизняних педагогів достатньо повно висвітлюється питання патріотичного виховання дітей та молоді, представлені сучасні методики (І. Бех, В. Кириченко, Ж. Петрочко та ін.). Дослідженням професійної підготовки майбутніх офіцерів та розробкою новітніх науково-педагогічних методик 3 патріотичного виховання військовослужбовців переважною більшістю займаються військові педагоги та психологи, останніми з яких виділяємо наукові праці В. Воробйової, Т. Іноземцева, Ю. Ковтун, О. Колесніченка, Я. Мацегора, I. Приходько та ін. Військова педагогіка має особливі специфічні відмінності від загальної, а їі методологія відрізняється акцентуванням на готовність військовослужбовців до діяльності в особливо небезпечних для життя умовах. Для готовності військовослужбовців професійно діяти в умовах загрози життя необхідна потужна мотиваційна складова, невід'ємною частиною, якої $\epsilon$ саме духовно-патріотичне ставлення до своєї справи. Сучасні наукові дослідження проблем патріотичного виховання, стану духовного розвитку та загальних політичних настроїв українського суспільства необхідно постійно враховувати до навчально-виховного процесу, коригувати та оптимізувати його на кожному історичному етапі нашої країни.

Мета статті - охарактеризувати сучасні підходи до формування національної свідомості та патріотизму курсантів закладів військової освіти в умовах захисту України від посягань зовнішнього агресора.

Виклад основного матеріалу. В першу чергу необхідно підкреслити складну економічну та напружену політичну ситуацію у суспільстві в зв'язку з продовженням військової, економічної та політичної агресії з боку Росії, виходячи з чого на розвиток сучасних освітніх та методичних програм, спеціальних заходів не виділяється необхідний об'єм фінансування від держави. Отже, перед військовою педагогікою постає нелегке завдання компенсувати цю проблему за рахунок розробки науково-викладацьким складом ефективних педагогічних умов, пошуку ефективних форм та методів національнопатріотичного виховання курсантів закладів військової освіти, бо сьогодні переважна увага в сучасній реформації освіти, в тому числі військової, приділяється другорядним питанням, які мало сприяють підвищенню якості військового потенціалу держави, а самі реформи здійснюються урядом безпорадно та безсистемно.
Національна ідентифікація $€$ наріжним фактором формування патріотизму в державі, в основі якого закладена культурно-історична спадщина та національні духовні цінності. Особливість історичного розвитку України на шляху до незалежності полягає в тому, що вона дуже довгий час частково або повністю знаходилась під колоніальним ярмом інших країн, більше всього царської Росії та радянськомосковської диктатури. В цей час, колоніальною політичною стратегією правлячих держав було активне знищення етнічної та національної самобутності української нації, їі національної самосвідомості. За радянських часів до невпізнанності спотворювалися історичні факти та приховувалися цілі вехи національновизвольного руху, знищувалися документальні підтвердження геноциду та державних злочинів проти українського народу.

Саме відновлення національної самосвідомості українських військовослужбовців на зразках героїчної жертовності найкращих синів та дочок на всіх історичних етапах України задля отримання нею незалежності, повинно стати ключовим педагогічним завданням виховання майбутніх офіцерів. Захист країни для військовослужбовців - це визначений для них Конституцією України почесний обов'язок, але формування почуття самовідданості може відбутися тільки за умов національно-патріотичної самосвідомості кожного окремого громадянина $[3,60]$. Томуу військовій педагогічній методології необхідно розкривати комплексну складову патріотизму як високоморальну та духовну цінність. Головним призначенням військового патріотизму є консолідація та високий моральний рівень армії, особливо в умовах політичної та економічної кризи країни, для захистуїі цілісності та посягань ззовні.

Запорукою високоморального відношення військової молоді до своєї країни може стати прищеплення їм відповідальності за долю держави, поваги до українського народу та належності до України. Дуже важливим в такому педагогічному процесі $є$ індивідуальний підхід до розвитку кожної окремої особистості 3 урахуванням особистісних якостей кожного курсанта, стану сформованої його свідомості, звичок та традицій виховання. Виховування у курсантів почуття державної єдності всього народу України, незалежно від національного походження та віросповідання, надасть змогу сформувати у молодого покоління толерантне ставлення до всіх, хто ототожнює себе частиною українського суспільства. Важливим фактором 


\section{СУЧАСНІ ПЦДХОДИ ДО ФОРМУВАННЯНАЦІОНАЛЬНОЇ СВІДОМОСТІТАПАТРІОТИЗМУ У КУРСАНТІВ ЗАКЛАДІВ ВІЙСЬКОВОЇ ОСВІТИ}

такого ставлення повинно стати розуміння спільної культурної спадщини, любові до рідної землі та шанування героїчних особистостей, які боролися та сприяли народженню незалежної України.

Вітчизняні педагоги “військово-патріотичне виховання” визначають складником патріотичного виховання, що забезпечує активну участь громадян у збереженні безпеки своєї країни від зовнішньої агресії, сприяє готовності молоді до захисту своєї батьківщини, потребам здобувати військову професію, проходити службу у Збройних Силах України [2, 128].

Сучасна державна програма патріотичного виховання у всіх закладах освіти (від дошкільних до вищих) до цього часу працює частково i вибірково. Вона працює за принципом організації окремих заходів пов'язаних 3 календарними святами чи сумними роковинами трагічних військових подій, тобто, як прийнято казати, за остаточним принципом. Значна кількість молоді уникає участі в патріотичних заходах, а дані статистики підтверджують те, що з кожним роком збільшується кількість молодих фахівців, які мігрують за кордон. Тому на сучасному етапі виховання нових поколінь офіцерів-патріотів, здатних самовіддано захищати суверенітет, незалежність, демократичні принципи та верховенство права, стає питанням майбутнього України. Особлива, навіть ключова роль в процесі зміцнення патріотичного стержню держави належить безпосереднім захисникам країни, тобто військовослужбовцям. Історичні приклади доводять, що саме позиція армії та ії офіцерської еліти вигравала вирішальну роль у більшості випадків, коли політичні зрадники намагалися поступитися суверенітетом або територіальною цілісністю тих чи інших країн $[4,50]$.

Фундаментальна складова національнопатріотичного виховання в розвитку суспільства безумовно $€$ проблематикою історичного міжнародного значення, тому врахування досвіду інших країн в цьому напряму буде необхідним для вдосконалення вітчизняної педагогічної методології.

Багато країн у сучасному світі мають досвід багаторічних військових конфліктів та цілу низку їх трагічних та економічних наслідків. Одним із таких довготривалих військових конфліктів відбувається на Ближньому сході між Ізраїлем та Палестиною, що триває вже понад 70 років. За цей час державна політика Ізраїлю щодо військово-патріотичного виховання постійно вдосконалювалась, корегувалась та модернізувалась, що призвело до загальновизнаного на міжнародному рівні результату - Ізраїльська армія вважається однією із найсучасніших, ефективних та ідеологічно згуртованих армій у світі. Підвищені вимоги до життєвих настанов військовослужбовців, їх рівня самосвідомості та мотивації відіграють ключову роль у відборі особового складу армійських підрозділів. Суттєвою підтримкою готовності військових в Ізраїлі до патріотичної самовідданості $є$ високий рівень соціального забезпечення та соціальних гарантій для військовослужбовців у випадках отримання поранень, або їх родинам у випадку загибелі. Вони стовідсотково впевнені в тому, що держава максимально поважає їх здатність до жертовності і не залишить їх родини без соціальної уваги та гідної матеріальної підтримки. Саме тому в Україні необхідно вирішувати проблему соціальних гарантій та матеріального забезпечення військовослужбовців, службові обов'язки яких пов'язані з безпосередньою загрозою їх життя. Невпевненість в гідному матеріальному забезпеченні та соціальних гарантіях може звести нанівець педагогічний процес патріотичного виховання у певної частини курсантів закладів військової освіти

Не меншої уваги до патріотичного виховання приділяється у збройних силах США, хоча на території самої країни військові дії не відбувалися вже більше двохсот років. Бойовий досвід американських військовослужбовців накопичується постійною та активною участю у складі миротворчих контингентів в рамках ПівнічноАтлантичного військово-політичного альянсу НАТО. Американські військово-педагогічні методики спрямовані на переконання своїх військовослужбовців в тому, що якщо вони навіть знаходяться в зонах бойових дій на територіях інших держав, їх патріотична місія полягає в захисті інтересів миру у всьому світі та підтримки партнерів їхньої країни, тому їх діяльність відповідно пов'язана з захистом інтересів своєї держави [1]. Українські військовослужбовці теж приймають постійну участь у миротворчих контингентах багатьох країн, але їх чисельність значно менша і у деяких випадках обмежена присутністю тільки військово-технічних або медичних служб забезпечення. Мотиваційна складова українських миротворців, на відміну від американських, ніколи не базувалась на ствердженні про необхідність відстоювати інтереси України на території інших держав, але участь в таких контингентах завжди вважалась почесною, що також означає високий професійний рівень обраних для цієї місії військовослужбовців.

Ситуація докорінно змінилася в 2014 році, коли збройні сили України, знаходячись в майже 


\section{СУЧАСНІ ПІДХОДИ ДО ФОРМУВАННЯ НАЦІОНАЛЬНОЇ СВІДОМОСТІТАПАТРІОТИЗМУ У КУРСАНТІВ ЗАКЛАДІВ ВІЙСЬКОВОЇ ОСВІТИ}

знищеному стані, з застарілим, переважно ще за радянських часів озброєнням та обладнанням, мали протистояти зовнішній агресії з боку російських регулярних військ 3 сучасними військовими технологіями і озброєних ними найманців. Виключно хвиля самомобілізації патріотично налаштованої частини українського суспільства в добровільні батальйони, які з часом стали частиною нових регулярних військ, зупинила поглиблення сепаратизму i продовження захоплення російськими військами територій нашої держави.

Для збереження та підтримки патріотичного підйому в суспільстві, формування нового патріотичного покоління офіцерської еліти необхідна комплексна державна програма підтримки національно-патріотичного виховання військової молоді та гідний рівень їх соціального забезпечення. Мотиваційна складова (матеріальне забезпечення) викладацького складу персоналу закладів військової освіти також відігріває значущу роль в якості педагогічного процесу, адже на відміну від комерційних закладів освіти, державні військові знаходяться виключно на державному забезпеченні і не мають додаткових джерел фінансування.

Занепад нашої країни на сучасному історичному етапі, пов'язаний в тому числі 3 величезною проблемою корумпованості чиновників та керівництва держави, яка працює тільки для власного збагачення та утримання влади. Багаторічне нехтування необхідністю модернізувати державне управління за всі роки незалежності України до вирішення проблем соціальної захищеності офіцерської професії призвели до катастрофічного падіння престижності військової служби [5]. Відсутність належної уваги до патріотичного виховання в закладах військової освіти та патріотично виховної роботи в армії призвели до загального падіння рівня духовно-моральних цінностей українських офіцерів. Молоді офіцери, які закінчували військові заклади освіти за останні 25 - 30 років, мали розмите розуміння патріотичних якостей військовослужбовця, вкрай низьке почуття національної гідності та відсутній ідеологічний базис, тому зараз, на хвилі емоційного патріотичного зростання, ми маємо дбати про справжніх свідомо національно-патріотично налаштованих офіцерів, які будуть не тільки захищати нашу державу, але і дбати про майбутнє “оздоровлення нації”.

Високий рівень військової підготовки, досвідченість, аналітико-пізнавальна активність (здатність до навчання), цілеспрямованість, сильна воля, психологічна стійкість, громадянська позиція та національно-патріотична свідомість визначаються як основні риси сучасного високопрофесійного офіцера, тому пріоритетом в формуванні та розвитку службових якостей курсантів має бути впровадження новітніх методів патріотичного виховання та вдосконалення просвітницько-виховних методологій 3 застосуванням інноваційних освітніх технологій.

Першим та найбільш ефективним педагогічним інструментарієм в процесі прищеплення курсантам національно-патріотичної свідомості має стати поглиблене вивчення історії багатовікового національно-визвольного рухуукраїнського народу, 3 використанням можливості вивчати досі невідомі історичні документи, які протягом довгого періоду приховували в секретних архівах ворогами української незалежності. Фундаментальні знання з історії розвитку людства в контексті історичного розвитку військової науки і техніки, застосування багатовікового досвіду ведення військових дій у сучасних умовах обов'язково потрібні майбутнім офіцерам для формування (розвитку) стратегічного мислення. Але всі суто військові та загальні освітні предмети та програми спрямовані на здобуття курсантами виключнопрофесійних компетентностей і тільки програма патріотичного виховання може мотивувати їх на прояв ініціативи, щоб знайти власне рішення в непередбачених освітою ситуаціях.

Спотворені царською, потім радянською владою, а в наш час російською пропагандою історичні факти існування української державності, розвитку самобутньої української культури і національної індивідуальності вже завдали величезної шкоди процесу самоідентифікації більшої частини українського суспільства, і в тому числі військовому офіцерському кадровому складу України, стандарти якої довгий час базувалися на ідеології радянських часів. Але основи морально-духовних цінностей для професійних офіцерів, які мають загальнолюдські зразки залишаються незмінними незалежно від зміни політичного устрою держав - це здатність до жертовності заради своєі Батьківщини, гуманізм, чесність та почуття справедливості, високий рівень відповідальності за свою справу та дисциплінованість. До цього переліку необхідно додати такі обов'язкові якості військової еліти як висока етика поведінки в службовому спілкуванні та особистому житті, навички критичної самооцінки, наявність лідерських якостей та можливість до швидкої адаптації в нових складних умовах. 


\section{СУЧАСНІ ПІДХОДИ ДО ФОРМУВАННЯНАЦІОНАЛЬНОЇ СВІДОМОСТІ ТАПАТРІОТИЗМУ У КУРСАНТІВ ЗАКЛАДІВ ВІЙСЬКОВОЇ ОСВІТИ}

Зміцненню морально-духовних якостей, а як наслідок формування патріотичного становлення курсантів, сприяє переконання їх в необхідності дотримання здорового, спортивного образу життя. На прикладах демонстрації документальних стрічок та наведення статистичних даних щодо нещасних випадків, кримінальних злочинів та руйнування здоров'я, кар'єри і особистого життя серед тих хто зловживає алкоголем або вживає наркотичні речовини, необхідно зафіксувати у курсантів природній рефлекс негативного ставлення до цих явищ, як до суспільної хвороби нації, що знищує не тільки саму людину, але і його родину і близьке оточення.

Для ефективної організації національнопатріотичного процесу виховання майбутніх офіцерів, військовим педагогам потрібно застосувати комплексний підхід до підготовки та проведення педагогічно-патріотичних заходів, а саме:

- обов'язково проводити регулярну діагностику емоційно-вольового та мотиваційного рівня курсантів та їх когнітивної готовності до діяльності в особливо-складних та ризикованих умовах;

- застосовувати індивідуальний підхід до кожного окремого курсанта для встановлення в процесі спілкування відчуття довіри та взаємоповаги, відокремлюючи групові інтереси від особистісних та робити акцент у виховному процесі на пріоритеті суспільної значущості над особистими бажаннями;

- моделювати різноманітні особливі ситуації та знаходити варіанти поведінки в їх умовах 3 урахуванням індивідуальних особливостей та патріотичної свідомості кожного окремого курсанта;

- організовувати педагогічно-виховні ситуації для формування колективної патріотичної свідомості курсантів та зацікавлювати їх участю у військово-патріотичних заходах;

- під час проведення виховних заходів використовувати сугестивний метод (навіювання) для корегування системної шкали життєвих інтересів, планів, та переконання курсантів в необхідності якісного виконання особистих або колективних доручень;

- розподіляти між курсантами окремі відповідальні доручення в процесі проведення військово-патріотичних заходів відповідно рівня їх готовності до такої діяльності;

- розробляти цікавий зміст військовопатріотичних заходів із застосуванням дидактичного методу виховання та знаходити для цього різноманітну, у тому числі новітню інформацію, організовувати нестандартні умови проведення в значущих місцях із використанням всього можливого прикладного обладнання;

- використовувати перцептивні функції спілкування та рефлексивного мислення під час виховного процесу для можливості передбачення індивідуальної реакції курсантів;

- використовувати сучасні форми та методи у навчально-виховному процесі (метод фасилітації, баскет-метод, мозковий штурм, поведінкове моделювання, тренінги та ін.).

Висновки. Таким чином, маючи стратегічний державний план розвитку національнопатріотичного виховання молоді, з урахуванням особливості та значущості його в процесі підготовки курсантів закладів військової освіти та використовуючи природній підйом патріотичної свідомості суспільства в умовах російської агресії проти України, можна розраховувати на формування нового патріотично налаштованого покоління, яке стане фундаментом та запорукою суверенного та економічного розвитку країни. Зростання патріотичної свідомості курсантів закладів військової освіти надасть можливість розвинути цілу низку їх особистісних якостей, які підвищать рівень професіоналізму, відчуття особистої соціальної значущості, прагнення до професійної самопідготовки, саморозвитку та самовдосконалення для ефективної реалізації професійних завдань.

До перспективних напрямків подальших досліджень педагогічних методів національнопатріотичного виховання курсантів закладів військової освіти необхідно віднести вивчення практик застосування новітніх інноваційних технологій в інформаційному просторі, розуміння механізму яких надасть їм можливість розпізнавати гібридну ворожу пропаганду із загального інформаційного потоку для запобігання психологічних маніпуляцій із підсвідомістю.

\section{ЛІТЕРАТУРА}

1. Брижатий $С$. І. Порівняльний аналіз формування професійної готовності офіцерів в арміях провідних країн світу. Збірник наукових праць Хмельницького інституту соиіальних технологій Університету “Україна". 2012. № 5. С. 20-25.

2. Бех, І. Д., Кириченко, В. І., Петрочко Ж. В. 3 Україною в серці (тренінг з патріотичного виховання дітей та молоді) : посіб. Харків, 2016. 140 с.

3. Іноземцев Т. В. Підготовка майбутніх офіцерів до виховної роботи у Збройних силах України. “Молодий вчений”. № 10 (62). 2018 р. С. 59-62.

4. КовтунЮ. В. Патріотичневиховання військовослужбовців як основа становлення української національної еліти. Вісник Житомирського державного університету 
імені Івана Франка. Філософські науки. 2016. Вип. 1. C. $49-53$.

5. Психологічна готовність військовослужбовців Національної гвардії України до службово-бойової діяльності поза межами пункту постійної дислокації : монографія / О. С. Колесніченко, Я. В. Мацегора, В. І. Воробйова та ін. Х. : Національна акад. НГУ, 2016. $335 \mathrm{c}$.

\section{REFERENCES}

1. Bryzhatyi, Ye. I. (2012). Porivnialnyi analiz formuvannia profesiinoi hotovnosti ofitseriv v armiiakh providnykh krain svitu [Comparative analysis of formation of professional readiness of officers in the armies of the leading countries of the world]. Collection of scientific works of the Khmelnytskiy Institute of Social Technologies of the "Ukraine" Univer. No. 5, pp. 20-25. [in Ukrainian].

2. Bekh, I. D., Kyrychenko, V. I. \& Petrochko, Zh. V. (2016). Z Ukrainoiu v sertsi (treninh z patriotychnoho vykhovannia ditei ta molodi) : posib. [With Ukraine in the heart (training on patriotic education of children and youth):manual]. Kharkiv, 140 p. [in Ukrainian].

3. Inozemtsev, T. V. (2018). Pidhotovka maibutnikh ofitseriv do vykhovnoi roboty u Zbroinykh sylakh Ukrainy [Preparation of future officers for educational work in the Armed Forces of Ukraine]. "The Young Scientist". No.10 (62), pp. 59-62. [in Ukrainian].

4. Kovtun, Yu. V. (2016). Patriotychne vykhovannia viiskovosluzhbovtsiv yak osnova stanovlennia ukrainskoi natsionalnoi elity [Patriotic education of servicemen as a basis for the formation of the Ukrainian national elite]. Bulletin of Zhytomyr State University named after Ivan Franko. Philosophical sciences. Vol. 1, pp. 49-53. [in Ukrainian].

5. Kolesnichenko, O. S., Matsehora, Ya. V. \& Vorobiova, V. I (2016). Psykholohichna hotovnist viiskovosluzhbovtsiv Natsionalnoi hvardii Ukrainy do sluzhbovo-boiovoi diialnosti poza mezhamy punktu postiinoi dyslokatsii [Psychological readiness of the servicemen of the National Guard of Ukraine to military service beyond the point of permanent disposition]. Kharkiv, 335 p. [in Ukrainian].

Стаття надійшла до редакції 04.03.2019

УДК 373.2.091.33-027.22

DOI:

Віолета Городиська, кандидат педагогічних наук, доцент кафедри загальної педагогіки та дошкільної освіти Дрогобииького державного педагогічного університету імені Івана Франка

\section{ЗМІСТОВІ АСПЕКТИ ПІДГОТОВКИ СВЯТ ТА РОЗВАГ У ЗДО}

У статті висвітлено зміст понять “свято” та “розвага”; розкрито мету їхньго проведення в закладах дошкільної освіти та значення для різностороннього розвитку дітей; здійснено аналіз чинних освітніх програм дошкільної освіти щуодо напрямів реалізації свят та розваг у ЗДО; акцентовано увагу на парціальних програмах “Стежина” та “Веселкова музикотерапія”, у яких найтрунтовніме представлено змістові аспекти підготовки свят і розваг у сучасних закладах дошкільної освіти.

Ключові слова: свята; розваги; естетичне виховання; художньо-естетичне виховання; музичне виховання дошкільників.

תim. 15.

Violeta Horodyska, Ph.D.(Pedagogy), Associate Professor of the General Pedagogy and Preschool Education Department, Drohobych Ivan Franko State Pedagogical University

\section{SEMANTIC ASPECTS OF PREPARATION OF HOLIDAYS AND ENTERTAINMENT FOR CHILDREN IN PRESCHOOL EDUCATION STUDIES}

The article covers the meaning of the concepts "holiday" and "entertainment"; the purpose of their conduct in the pre-school establishments and importance for the diverse development of children is revealed; the analysis of the existing educational programs of preschool education concerning directions of realization of holidays and entertainments in institutions of preschool education; The most promising educational program for this intelligence - "The Path", as well as the partial "Rainbow Music Therapy", is elaborated, in which the substantive aspects of preparation of holidays and entertainments in modern institutions of preschool education are presented in the most comprehensive way.

The attention of teachers of preschool establishments is to focus on traditional local customs, distinctive national peculiarities of musical culture, cultural-regional traditions, rituals, and adapt them to the specifics of a preschool institution.

After analyzing the software for modern pre-school establishments ("Ukrainian preschool", "Child" "Child in preschool years", "Sunflower", "Confident start", "I in the world", "The world of childhood", "The Path"), and as well as the "Rainbow Music Therapy" and "Joy of Creativity" partial programs, we conclude that the problem 